\title{
Child Friendly Culture in the Education System in Indonesia
}

\author{
Muhdi $^{1^{*}} \quad$ Wahyu Widodo ${ }^{2}$ Toebagus Galang ${ }^{2}$ \\ 1. Faculty of Education Universitas PGRI Semarang \\ 2. Faculty of Law Universitas PGRI Semarang
}

\begin{abstract}
Child friendly culture, which is a culture that puts forward the main principles of non-discrimination of interests, the right to life and respect for children. As mandated in the article 4 of Law No.23 of 2002 concerning child protection which states that children have the right to be able to live to grow, develop, and participate appropriately according to human dignity and dignity, as well as get protection from violence and discrimination. But has this child-friendly culture been effectively implemented in the Indonesian education system ? this is the concern of the writing team which the writing team made the subject of for in-depth study with the post-positivism paradigm, with a conceptual approach with the expected results in the form of analytical descriptions. The results showed that the Effectiveness of the Implementation of Child Friendly Culture in the Education System in Indonesia is not as simple as merely looking at teaching and learning activities, but more broadly including appropriate school programs, a supportive school environment and adequate facilities and infrastructure. This matter by the author will be discussed thoroughly. The results showed that of the three aspects that have been postulated by the author, Indonesia is still unable to apply child-friendly culture properly in the education system. Reflecting on this, the effort to be able to create a child-friendly culture is to create a conducive atmosphere in school, society and family so that students feel comfortable and can express their potential.
\end{abstract}

Keywords: Child Friendly Culture, Education System, Indonesia

DOI: $10.7176 / \mathrm{JEP} / 11-3-03$

Publication date: January $31^{\text {st }} 2020$

\section{Introduction}

Children are the next generation of the nation and therefore they need a lot of attention from the government so that child development can run well. Reflecting on this, in order to be able to create an atmosphere of good child development, the government devoted special attention to the education system.

The education system in Indonesia was basically founded with the noble intention of advancing the nation's intelligence even though it has many shortcomings in some parts such as the teaching sector where the competence of educators in the country with the fourth largest population in the world is classified as very low. Data from the Ministry of Education and Culture shows, among the 1.6 million participants of the teacher competency test, more than 1.3 million of them have grades below 60, from a range of grades from 0 to 100 . From this test also, only 192 teachers who scored above 90 . While almost 130,000 of them were only able to get scores below 30.(ITS;2019)

Aside from the problems mentioned above, other problems that are quite interesting to study are in relation to students. In providing teaching to students, the education system in Indonesia which was originally designed so that humans can find their identity along with the changing times to advance according to what employment needs. This results in the education system in Indonesia being only concerned with results, not processes so that in following this "process" it is not uncommon for students to experience violence. Although Indonesia already has a Child Protection Act and a special institution that protects children, the trend of cases of violence against children continues to increase. The Child Protection Task Force itself advocated 52 cases of child violence that have not been resolved.(Kominfo;2019)

Conceptually, the law defines the protection of children in each and every of their activities so that the children can live their life and develop their skills in to make a better future of the nation so in order to do that the cihldren need to receive protection from violence and discrimination. In a regulatory perspective, the State has provided its legal umbrella since 2002 as outlined in Law No. 23 of 2002 concerning child protection. However, in its development, the law was amended to change in order to respond to the times. The change is stated in Law No. 35 of 2014.

In examining several cases of violence, child abuse, or similar acts, the comments of observers and observers by referring to certain theories indicate something is wrong with the community or its tradition, but on the other hand, there are also some people who propose and make offers to include the contents of "child protection" in the education system. One way is through a child-friendly culture, which is a culture that promotes the main principles of non-discrimination of interests, the right to life and respect for children. As mandated in the article 4 of Law No.23 of 2002 concerning child protection which states that children have the right to be able to live to grow, develop, and participate appropriately according to human dignity and dignity, as well as get protection from violence and discrimination. However, has this child-friendly culture been effectively implemented in the Indonesian education system? this is the concern of the writing team which the writing team made the issue to be 
studied in depth in order to find that this child-friendly culture has been implemented effectively in the Indonesian education system.

\section{Method of Research}

The paradigm used in this paper is the Post-Positivism paradigm, which is used by the writing team as a basis for studying the education system in Indonesia in relation to child-friendly culture(Guba\&Lincoln;2005). In this study, researchers used three approaches, namely: Conceptual Approach, Statutory Approach, Statutory Approach carried out by examining all regulations relating to the subject matter. The legislative approach in normative legal research has practical and academic uses (Peter;2005) as the result of this study are expected to provide descriptive analytical descriptions. The type of data needed in this study are primary data and secondary data. Analysis of the data used in this research is qualitative data analysis. Then the results of data analysis are interpreted in the form of inductive conclusions which are answers to problems based on research results. The type of triangulation used in this study is data triangulation, situational and data collection methods. Data triangulation is done by taking data from various situations, times and places.

\section{Discussion}

\subsection{Child Friendly Culture in the Education System in Indonesia}

Children are the next generation that will succeed the future of a nation and as such they need special protection and care including legal protection that is different from adults. This is based on physical and mental reasons of children who are not yet mature and mature. Children need to get a protection that has been contained in a statutory regulation. Every child will be able to assume these responsibilities, so he needs to get the most opportunity available to develop physically, mentally, socially, as much as possible with a noble efforts to protect and to realize the welfare of children by providing guarantees for the fulfillment of their rights. their rights and the existence of non-discriminatory treatment realized through the adoption of a child-friendly culture in the education system.

A Child Friendly Culture is a culture that consciously seeks to guarantee and fulfill children's rights in every aspect of life in a planned and responsible manner. The main principle is non-discrimination of interests, the right to life and respect for children. As stated in article 4 of Law No.23 of 2002 concerning the protection of children, it states that children have the right to be able to live to grow, develop, and participate appropriately according to human dignity and dignity, and to get protection from violence and discrimination. Mentioned above is one of them. is participating which is spelled out as the right to hold opinions and be heard. Child Friendly Culture is an open culture involving children to participate in all activities, social life, and encourage the growth and welfare of children.

In an effort to create a Child Friendly Culture, it needs to be supported by various parties, including families and communities who are actually the closest education centers for children. A supportive, protecting environment that provides a sense of security and comfort for children will greatly assist the process of finding identity. Children's habits have a tendency to imitate, try and seek recognition of their existence in the environment in which they live.(Suherman;2009)

To be able to realize a child-friendly culture in the school environment, there are several principles that can be applied to build child-friendly schools, including:

1. Schools are required to be able to present themselves as a media, not just a pleasant place for children to learn.

2. Children's world is "playing". It is in playing that the child actually does the process of learning and working. The school is a playground that introduces fair competition in a teaching-learning process.

3. Schools need to create space for children to talk about their school. The goal is to make a dialectic between the values given by education to children.

4. Educators do not need to feel threatened by students' assessments because basically values do not add reality or substance to objects, but only values. Value is not an object or an element of objects, but rather the nature, quality, suigeneris possessed by certain objects which are said to be "good".(Risieri;2001)

5. School is not a world separated from the daily reality of children in the family because the achievement of the ideals of a child cannot be separated from everyday reality. Limited hours of study and binding curriculum become obstacles to interpret deeper interactions between educators and children. To get around this, schools can hold special hours outside school hours that contain sharing between children and sharing between teachers and children about the reality of life in their respective families, for example: discussion of how relationships with parents, what are the reactions of parents when they get bad grades at school, or what parents expect of them. The results of the meeting can be a material for reflection in a subject matter delivered in class. This method is a strategy for educators to find out the condition of children because in some communities, children are considered a family investment, as a guarantee of a place to depend on old age.(Bagong;2019) 
In addition to that, schools must also create a conducive atmosphere so that children feel comfortable and can express their potential. In order to create a conducive atmosphere, there are several aspects that need attention, including the following :

1. Suitable School Programme

School programs must adapt to the children's environment, meaning that programs are adapted to the stages of growth and development of children. These program makes children automatically motivated to explore themselves, making them discover things they havent before in order to advance their skills. An important factor that schools need to pay attention to is the active participation of children in activities programmed that is Participation that grows because it suits the needs of the child.

In elementary school children and under the school program emphasizes more on function and less process, not emphasizing products or results.(Sujiono;2005) Product is only a consequence of function. In biological theory states "Function forms organs." Functions that are less activated will cause atrophy, and vice versa organs will be formed if enough functions. This is relevant if it is associated with a child's growth and development. Therefore, whatever activities are expected to not inhibit the growth and development of children, both related to physical, mental, and social. Usually with play activities, for example, these qualities can be used simultaneously. On the other hand, character values that should be owned by children can also be fostered as a result of the active participation of children.(Senowarsito;2012)

The strength of the school is mainly on the quality of the teacher, without ignoring other factors. The teacher has an important role in organizing quality learning. For elementary and kindergarten, teachers must have at least three potentials, namely: (1) have a sense of love for children (Having a sense of love to the children); (2) understanding the world of children (Having a sense of love to the children); and (3) able to approach children with the right method.(Thapa;2013)

2. Supportive school environment

The atmosphere of the school environment should be a place for children to learn about life. Especially schools that program their activities until the afternoon. The atmosphere of children's activities in the community is also programmed in school so that children still get the experiences that they should have in the community. For children the environment and atmosphere that allows for play is very important because playing for children is part of their lives. Even UNESCO stated "Right to play" (the right to play).

Basically, playing can be said as a miniature form of society. That is, the values that exist in society also exist in games or play activities.

If this atmosphere can be created at school, then the atmosphere in the school environment is very conducive to fostering children's potential because children can express themselves freely in accordance with their world.

In addition, the creation of a clean environment, access to healthy drinking water, free of germ nests, and adequate nutrition are important factors for children's growth and development.

3. Sufficient Facilities

The main infrastructure needed is related to the learning needs of children. Infrastructure does not have to be expensive but it is suitable to the needs of the child.

The existence of a safe zone to school, the existence of a non-smoking area, and an inclusive education is also a factor that is considered by schools. Schools also need to arrange a school environment and classes that are attractive, engaging, impressive, and nurturing patterns and individual approaches so that the school becomes a comfortable and pleasant place.

The school also guarantees children's participation rights. The existence of a children's forum, the availability of child-friendly information centers, the availability of creative and recreational facilities for children, the availability of class and school suggestion boxes, the availability of notice boards, the availability of children's magazines or newspapers. Schools should allow children to do things that include the right to express their views and feelings about situations that have an impact on children.

\subsection{Effectiveness of the Implementation of Child Friendly Culture in the Education System in Indonesia}

To be able to know how effective the application of a Child Friendly Culture to the Education System in Indonesia is not as simple as just looking at teaching and learning activities. The teacher indeed occupies an important position in implementing a child-friendly culture, but in practice but more broadly includes an appropriate school program, a supportive school environment and adequate facilities and infrastructure. This matter by the author will be discussed one by one.

In terms of appropriate school programs, this is certainly related to the curriculum currently used by education in Indonesia, the 2013 Curriculum (K13). This curriculum was made to replace the previous curriculum (KTSP). The 2013 curriculum has three aspects of assessment, namely aspects of knowledge, aspects of skills, and aspects of attitude and behavior. In the 2013 curriculum, especially in learning materials there are streamlined material and added material. The streamlined material is seen in Indonesian, Social Studies, PPKn, etc., while the material 
added is Mathematics.

Even though it has been used for a long time, this curriculum still has shortcomings such as the following(Mustari;2013) :

a. Contradiction, because they want to give birth to people who are creative, critical, innovative, but full of normative material because there are additional hours of religious study.

b. Second, hoping the learning process is more flexible but there are only adding an extra hours of study in class.

c. Third, the 2013 curriculum is suitable for schools that are already advanced and teachers have a high enthusiasm for learning, educated people, students have equal abilities and facilities, and the telecommunications and transportation infrastructure is evenly distributed so as not to impede the process.

d. Another drawback lies in the use of the National Examination (UN) as a standard evaluation of active student learning Process.

In terms of a supportive school environment, in this case it is closely related to facilities and infrastructure. as stated in $\mathrm{CNN}$ News(CNN;2019) that 75 percent of schools in Indonesia still do not meet the minimum standard of education services. This shows that education services are still uneven in remote areas. This condition is still added to the dropout rate in Indonesia which is still very high. Based on education data in 2010 mentioned, as many as 1.3 million children aged 7-15 years are threatened with dropping out of school. Actually the factors that influence dropout rates in Indonesia are very diverse, but the problem most often encountered is the matter of cost. The Center for Population and Policy Studies at Gadjah Mada University, found interesting facts from the results of research on scholarships in North Sumatra, West Java, East Java, West Nusa Tenggara, East Nusa Tenggara, and South Sulawesi.

It was stated that as many as 47.3 percent of respondents answered that they did not go to school anymore because of cost problems, then 31 percent because they wanted to help parents with work, and 9.4 percent because they wanted to continue non-formal education such as boarding schools or take other skills courses. Those who could not continue this school were mostly graduated from elementary school (42.1 percent) or did not have a qualification at all (30.7 percent).(Raharjo;2019)

With the enactment of Republic Act No. 23 of 2002 concerning Child Protection, it is expected that the conditions and protection of children will be better because the law contains the best protection for children, namely the right to life, growth and development, participation and protection of children from violence.

In an effort to protect children from violence, the Child Friendly School program specifically seeks to prevent violence against children in schools. Accessibility at school is easier than at home, for that school has a strategic role in preventing violence against children. For this reason, teachers need to know about preventing violence, including alternative ways of educating and disciplining children.(Sapto;2017)

This still shows that Indonesia has not been able to implement a child-friendly culture properly in the education system. Reflecting on this, the effort to be able to create a child-friendly culture is to create a conducive atmosphere so that students feel comfortable and can express their potential. In order to create a conducive atmosphere, there are several aspects that need attention, especially : (Wuri;2018)

1. Planning a school program that is appropriate to the stages of growth and development of students. Children do not have to be forced to do something, but they are being motivated to explore themselves, finding their expertise to hone their skills. An important factor that schools need to pay attention to is the active participation of children in various activities that are programmed, but according to the needs of children.

2. A supportive school environment. If this atmosphere can be created at school, then the atmosphere in the school environment is very conducive to fostering children's potential because children can express themselves freely in accordance with their world. In addition, the creation of a clean environment, access to healthy drinking water, free of germ nests, and adequate nutrition are important factors for children's growth and development.

3. Aspects of adequate infrastructure, especially those related to the learning needs of students. Infrastructure does not have to be expensive but it is suitable to the needs of the child. The existence of a safe and safe zone to school, the existence of a non-smoking area, an inclusive education is also a factor that is considered by the school. Structuring an attractive, engaging, impressive, and caring pattern of school and classroom environment and individual approach so that the school becomes a comfortable and enjoyable place.

In addition to that, in order to build a true child-friendly environment in education sector, the movement must not only focused in school only. The society and also the family must also be educated using the same principle as child-friendly schools. the schools, society and their family must also guarantee children's participation rights in activity that promotes their growth. The existence of a children's forum, the availability of child-friendly information centers, the availability of creative and recreational facilities for children, the availability of class and 
school suggestion boxes, the availability of notice boards, the availability of children's magazines or newspapers. Schools, society and their family should allow children to do things that include the right to express their views and feelings about situations that have an impact on him.

Child-friendly schools, society and their family are institutions that recognize and respect the rights of children to obtain education, health, play and fun opportunities, protect from violence and abuse, can express views freely, and participate in making decisions according to their capacity. Schools, society and their family also share the same responsibilities for respecting the rights of others, pluralism and resolving differences without violence.

\section{Conclusion}

Based on the discussion presented above, it can be concluded that the effectiveness of the Implementation of a Child Friendly Culture in the Education System in Indonesia is not as simple as merely looking at teaching and learning activities, but more broadly including an appropriate school program, a supportive school environment and adequate facilities and infrastructure. This matter by the author will be discussed one by one. The results showed that of the three aspects that have been postulated by the author, Indonesia is still unable to apply childfriendly culture properly in the education system. Reflecting on this, the effort to be able to create a child-friendly culture is to create a conducive atmosphere in school, society and family so that students feel comfortable and can express their potential.

\section{References}

Bagong Suyanto, (2019), "Sosiologi Anak”, Kencana, Yogyakarta. P.323.

Guba \& Lincoln, (2005), "The Sage Handbook Of Qualitative Research Third Edition, Sage Publication, London". p. $89-115$

Mustari, Muhamad and Rahman, M Taufiq,(2013), "Manajemen Pendidikan", Raja Grafika Persada, Jakarta.

Peter Mahmud Marzuki.(2005), "Penelitian Hukum”. Prenada Media Group, Jakarta. p. 136.

Raharjo, Sabar Budi., (2019), "Evaluasi Trend Kualitas Pendidikan Di Indonesia. Jurnal Penelitian dan Evaluasi Pendidikan", [S.1.], v. 16, n. 2, p. 511-532, jan. 2013. ISSN 2338-6061. Available at: $<$ https://journal.uny.ac.id/index.php/jpep/article/view/1129>. $\quad$ Date $\quad$ accessed: $31 \quad$ dec. 2019. doi:https://doi.org/10.21831/pep.v16i2.1129.

Risieri Frondizi,(2001), "Pengantar Filsafat Nilai”, Pustaka pelajar, Yogyakarta. P. 9.

Sapto Budoyo, Gunarto, Jawade Hafidz,(2017), “Desperate needs of teacher's law protection as a professional educator in Indonesia", International Journal of Multidisciplinary Research and Development, Vol. 4, Issue 7 (2017).

Senowarsito Senowarsito, Arisul Ulumuddin,(2012), "Media Penelitian Pendidikan", Vol 6 (1) Tahun 2012, http://dx.doi.org/10.26877/mpp.v6i1.360

Suherman Eman.,(2009), "Model Belajar dan Pembelajaran Berorientasikan Kompetensi Siswa”. Bandung : Universitas Pendidikan Indonesia

Sujiono, B. dan Yuliani Nurani, (2005)." Pembelajaran Anak Usia Dini". Jakarta : Yayasan Citra Pendidikan Indonesia

Thapa, A., Cohen, J., Guffey, S., \& Higgins-D’Alessandro, A., (2013), “A review of school climate research". Review of Educational Research, 83(3), 357-385. https://doi.org/10.3102/0034654313483907

Wuri Wuryandani, Faturrohman Faturrohman, Anwar Senen, Haryani Haryani, (2018), "Implementasi pemenuhan hak anak melalui sekolah ramah anak", Jurnal Civics Media Kajian Kewarganegaraan Vol 15 No (1) Tahun 2018, http://dx.doi.org/10.21831/jc.v15i1.19789

https://kominfo.go.id/content/detail/5272/indonesia-darurat-kekerasan-pada-anak/0/sorotan media Date Accessed on 15 December 2019

https://www.cnnindonesia.com/nasional/20141201134529-20-14960/sebanyak-75-persen-sekolah-di-indonesiatak-penuhi-standar Date Access 31 December 2019

https://www.its.ac.id/news/2019/05/02/menyoal-sistem-pendidikan-di-indonesia/ Date Accessed on 15 December 2019 